\title{
Matematik Eğitimi Alanında Yazılan Lisansüstü Deneysel Tezlerin İncelenmesi: Bir Meta-Analiz Çalışması ${ }^{1}$
}

\section{Examining Postgraduate Experimental Theses in Mathematics Education: A Meta-Analysis Study}

\author{
Gökhan ER ${ }^{2}$, Abdullah Çağrı BİBER ${ }^{3}$
}

\begin{tabular}{|c|c|}
\hline $\begin{array}{l}\text { Anahtar Kelimeler } \\
\text { Matematik eğitimi, } \\
\text { Meta-analiz, } \\
\text { Deneysel } \\
\text { araştırmalar, } \\
\text { Lisansüstü tezler. }\end{array}$ & 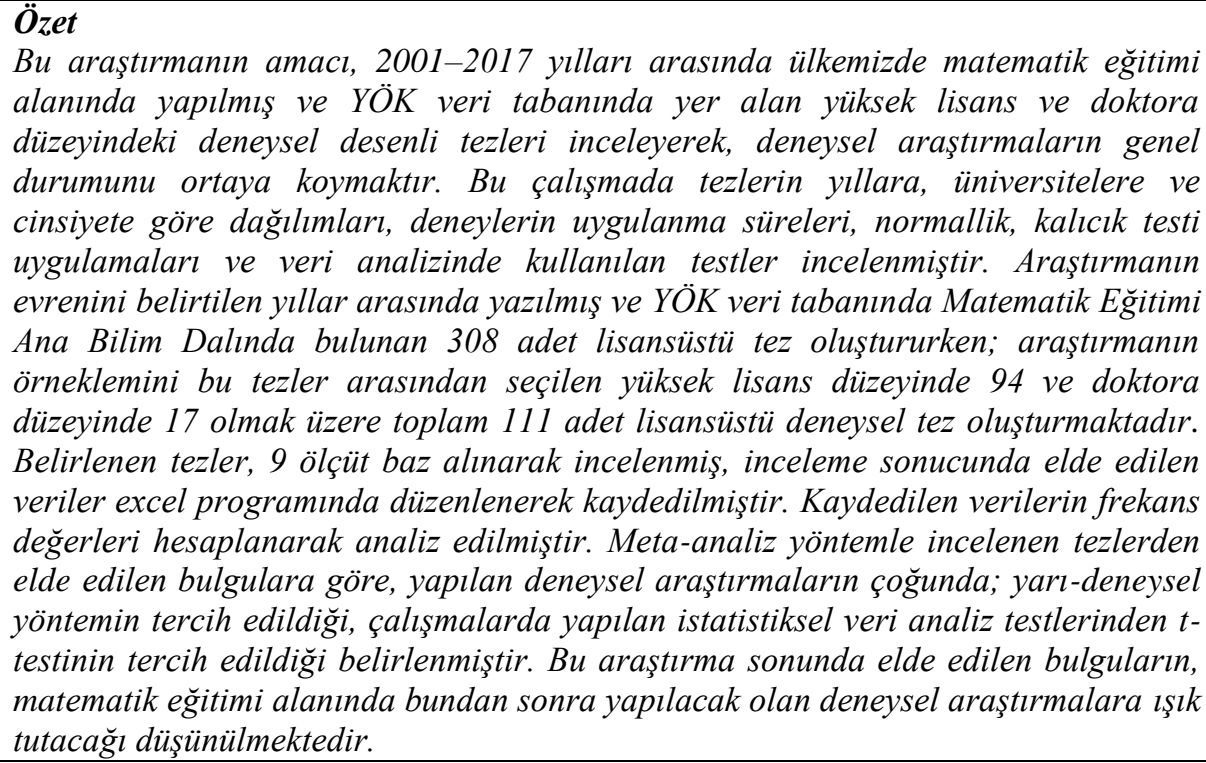 \\
\hline $\begin{array}{l}\text { Key Word } \\
\text { Mathematics } \\
\text { Education, } \\
\text { Meta-analysis, } \\
\text { Experimental } \\
\text { research, } \\
\text { Graduate theses. }\end{array}$ & $\begin{array}{l}\text { Abstract } \\
\text { The aim of this study is to reveal the general situation of experimental researches by } \\
\text { examining the master and doctorate theses with experimental design in the field of } \\
\text { mathematics education in our country between 2001-2017. In this study, the } \\
\text { distribution of theses by years, universities and gender, duration of application of } \\
\text { experiments, normality and permanence test applications and tests used in data } \\
\text { analysis were examined. The universe of the research consists of } 308 \text { graduate theses } \\
\text { written in the mentioned years and included in the YÖK (Institution of Higher } \\
\text { Education) Database in the Department of Mathematics Education, the sample of the } \\
\text { research consists of } 111 \text { graduate theses, } 94 \text { of which are at the master's level and } \\
17 \text { at the level of doctorate. The theses were examined based on } 9 \text { criteria and the } \\
\text { data obtained were arranged in excel program and recorded. Frequency values of } \\
\text { recorded data were calculated and analyzed. According to the findings obtained } \\
\text { from the theses examined with the meta-analysis method, it was determined that the } \\
\text { quasi-experimental method was preferred in most of the experimental researches } \\
\text { and the t-test was used in the data analysis. It is thought that the findings obtained } \\
\text { from this research will shed light on the experimental researches in the field of } \\
\text { mathematics education. }\end{array}$ \\
\hline
\end{tabular}

Atıf için: $\quad$ Er, G., \& Biber, A. Ç. (2020). Matematik eğitimi alanında yazılan lisansüstü deneysel tezlerin For Citation incelenmesi: Bir meta-analiz çalışması. Muğla Sıtkı Koçman Üniversitesi Eğitim Fakültesi Dergisi [MSKU Journal of Education], 7(1), 24-34. DOI: 10.21666/muefd.646744

Received: 14.11.2019 Accepted: 13.03.2020 $\quad$ Published: 01.05.2020

\footnotetext{
${ }^{1}$ Bu makale birinci yazarın yüksek lisans tezinin bir bölümü olarak hazırlanmıştır.

${ }_{2}$ MEB, Matematik Ögrretmeni, Sakarya, brave_mesk@hotmail.com, ORCID 0000-0002-8096-7742

з Kastamonu Üniversitesi, İlköğretim Matematik Ana Bilim Dal, acbiber@gmail.com, ORCID 0000-0001-7635-3951
} 
Bir araştırma sürecinde değişkenleri ölçebilmek ve bu değişkenlere bağlı olarak sebep-sonuç ilişkilerini ortaya çıkarmak için genellikle deneysel yöntem tercih edilmektedir. Eğitim bilimlerinde yeni geliştirilen bir materyalin veya yeni bir yaklaşımın öğrenci başarısına olan etkisini incelemek için nicel verileri toplamak amacıyla yapılan çalışmalarda deneysel yöntem kullanılmaktadır (Elliot, 2005; Çepni, 2012; Büyüköztürk, 2018). Tam deneysel araştırmalarda doğal olmayan bir araştırma ortamı oluşturularak bir veya birden çok deney grubunu temsil edecek şekilde bir veya birden çok kontrol gurubu seçilir. Grupların seçiminde en önemli nokta öğrenci dağılımının rasgele olacak şekilde yapılmasıdır. Bunun temel nedeni grupların oluşturulma aşamasında dışarıdan kaynaklı ortaya çıkabilecek olumsuzlukları ortadan kaldırmaktır (Altunışık, Coşkun, Bayraktaroğlu ve Yıldırım, 2005; Fraenkel \& Wallen, 2006). Araştırmada deneklerin deney ve kontrol gruplarına rasgele dă̆ıtılması mümkün olmayan durumlarda ise yarı deneysel yöntem tercih edilmektedir (Cohen, Manion ve Morrison, 2000). Ülkemizdeki okullarda merkezi eğitimin uygulanması ve araştırmacıların sınıfları rasgele atama yoluyla oluşturması mümkün olmadığında yürütülen eğitim araştırmalarında daha önceden oluşturulmuş sınıflar deney ve kontrol gurubu olarak kullanılmaktadır (Gürbüz ve Şahin, 2014). Tek denekli araştırma sadece bir deneğe ilişkin bulguların elde edilerek yorumlandığ yarı deneysel bir araştırma türüdür (Robson, 1998; Karasar, 1999; Can, 2018; Büyüköztürk, 2018).

Araştırmalarda, bir yöntemin denenmesi sürecinde durumu sabit tutulan ve herhangi bir değiş̧ene maruz bırakılmayan kontrol grubu, deney sürecinde karşılaştırma için kullanılan gruptur. Deney grubu ise, araştırmada etkisi incelenen değiş̧kenin süreçte uygulandığ 1 ve değişimlerin gözlendiği gruptur (Elliot, 2005; Fraenkel \& Wallen, 2006). Deneysel çalışmalarda seçilecek örneklemin seçileceği elemanları bakımından evreni temsil edebilmesi ve evren üzerindeki dağılımının yeterli düzeyde olması araştırmanın bilimselliği açısından gereklidir (Çıngı, 1994; İşçil, 1997). Normal dağılım, veri dağılımlarının doğada bulunuş şekillerine göre dağılış göstermesidir (Çıngı, 1994; Çepni, 2012; Can, 2018). Araştırmalarda normal dağılım, verilerin analiz edilmesinde kullanılacak olan istatistiksel testlerin seçiminde rol oynamaktadır. Veri dağılımının normal dağılması durumunda parametrik testler, normal dağılmaması durumunda ise parametrik olmayan testler kullanılmaktadır. Özellikle deneysel araştırmalarda dikkat edilmesi gereken normal dağılımın tespiti için istatistik programlar aracılığıyla normallik testleri (Kolmogorov Smirnov, Shaphiro Wilk vb.) uygulanmaktadır. Deneysel araştırmaların bilimsel etiğinin korunması ve doğru veri analiz testinin seçilmesi için araştırmalarda normallik testinin uygulanması gerekmektedir (Çepni, 2012; Gürbüz ve Şahin, 2014; Büyüköztürk, 2018). Veriler normal dağılmışsa uygulayacağınız testlere parametrik testler denir. Örnek büyüklüğü 30'dan büyük olmalıdır. Örneklem büyüklüğü 30'dan büyük olan testlerde parametrik testler parametrik olmayan testlere göre üstündür (Gökçe, 1992). Deneme yöntemi uygulanırken seçilen örneklemden elde edilen veriler normal dağılmamış olabilir. Parametrik olmayan denemeler, örneklemin sayısı matematiksel işlem yapılmayacak kadar küçük olduğu durumlarda tercih edilmektedir (Çıng1, 1994; Çepni, 2012).

Deneysel bir araştırmanın uygulanma sürecinin başında ön-test ve sürecin sonunda son-test uygulamaları yapılmaktadır. Bu uygulamaların amacı sürecin fayda düzeyini belirlemeye yönelik çalışmalardır. Bir değişkenin etkililik düzeyinin belirlenmesi için yapılan son-test uygulaması ile sürecin hemen sonunda anlık veri toplanmaktadır (Çepni, 2012; Can, 2018). Bu durum bazı dezavantajları ortaya çıkarmaktadır. Sürecin hemen sonunda uygulanıyor olması, istenilen bilgilerin taze olması ve testteki soruların kolaylıkla cevaplanması elde edilen verilerin kesin doğruluğunu sağlayamayabilir (Cebeci, 2002). Bu gibi durumların önüne geçmek için son-test uygulamasından belirli bir süre sonra deneysel süreçteki bağımsız değişkenin etkililik ve kalıcılık düzeyini tespit etmek amacıyla kalıcılık testi uygulaması yapılmaktadır. Kalıcılık testi, son-test uygulamasıyla aynı ya da benzer sorular içerebilir. Testin verimli uygulanma süresi 4 ila 6 hafta arasında değişmektedir (Elliot, 2005; Fraenkel \& Wallen, 2006; Balcı, 2010; Büyüköztürk, 2017).

Bu araştırmanın amacı, 2001-2017 yılları arasında ülkemizde matematik eğitimi alanında yapılmış ve YÖK veri tabanında yer alan yüksek lisans ve doktora düzeyindeki deneysel desenli tezleri inceleyerek, deneysel araştırmaların genel durumunu ortaya koymaktır. Bu çalışmada tezlerin yıllara, 
üniversitelere ve cinsiyete göre dağılımları, deneylerin uygulanma süreleri, normallik, kalıcık testi uygulamaları ve veri analizinde kullanılan testler incelenmiştir.

Matematik eğitimi alanında yayınlanmış araştırmaların incelendiği çalışmalara rastlanabilmektedir. Baki, Güven, Karataş, Akkan ve Çakıroğlu tarafından 2011 yılında yapılan çalışmada 1998-2007 yılları arasında matematik eğitimi araştırmalarındaki eğilimleri belirlemek amacıyla toplam 284 lisansüstü tezi doküman analizi tekniği ile incelenmiştir. Çalışmada, araştırma tasarımı olarak en fazla deneysel tasarımın kullanıldığı ve en fazla tercih edilen veri toplama aracının anket ve başarı testi olduğu sonuçlarına ulaşılmıştır. İlhan (2011) çalışmasında, matematik eğitimi alanında 2005-2009 yılları arası yayınlanmış olan 124 adet lisansüstü tez ve 219 adet ulusal makaleyi incelemiştir. İncelediği araştırmalarda deneysel araştırmaların yoğunlukta olması dikkat çeken bir sonuç olmuştur. İstatistiksel açıdan bakıldığında ise veri analizinde çalışmalarda betimsel istatistik, t-test ve ANOVA'nın en fazla kullanılan teknikler olduğu görülmektedir. Matematik eğitimi alanında 1982 ve 1998 yılları arasında yapılan ERIC veri tabanından ulaşılabilen araştırmaları inceleyen Lubiensky \& Bowen (2000), çalışmalarda en fazla araştırma yapılan konuların cinsiyet, etnik grup, sosyal sınıf ve imkân yetersizlikleri olduğu tespit etmişlerdir. Reed ve Owens (2000) tarafından yapılan bir diğer çalışmada, 2000 yılında ERIC (Education Resources Information Center) veri tabanında yayımlanmış olan araştırma raporları ve doktora tezleri ele alınmıştır. Matematik eğitimi alanındaki doktora tezlerinde incelenen başlıklar; tez yazarı, tezin başlığı, uygulanılan yöntem ve temel bulgular olurken, incelenen matematik eğitimi araştırmalarında ise makale yazarı, makale künye bilgileri, makale konusu ve temel sonuçları içeren bilgiler olmuştur.

Eğitim alanında meydana gelen değişiklikler, yeni öğretim modelleri ve yaklaşımların öğretim süreçlerine olan etkisinin araştırılma ihtiyacını da beraberinde getirmiştir. Bu durumla birlikte 2000'li yılların başından bu yana gelişen teknolojinin de etkisiyle eğitim alanındaki araştırmaların sayısında belirgin bir artış meydana gelmiştir. Bu gelişmelerden matematik eğitimi alanında yapılan deneysel araştırmalar da etkilenmiş ve bu alanda yapılan araştırmaların sayısı da aynı oranda artış göstermiştir. Ancak literatürde bu araştırmaların bulgularının birbirinden bağımsız olarak incelendiği bir çalışmaya rastlanılmamıştır. $\mathrm{Bu}$ nedenle bu çalışma, yapılan deneysel araştırmaların, genel bir çerçeve kullanılarak bilimsellik esasına dayanan deneysel araştırmalardaki eksikliklerin belirlenmesi, bu eksikliklerin sonraki çalışmalara yön göstermesi açısından büyük önem taşımaktadır.

Çalışmanın temel araştırma problemi "2001-2017 yılları arasında Matematik Eğitimi alanında tamamlanmış deneysel desenli lisansüstü tezlerin incelemesi nasıldır?" şeklinde ifade edilebilir. Bu bağlamda, soruya cevap aramak için aşağıda verilen alt problemler dikkate alınmıştır.

1. Deneysel desenli tezlerin sayıları yıllara göre nasıl bir değişim göstermektedir?

2. Deneysel desenli tezlerin üniversiteler bazında dağılımları nasıldır?

3. Araştırmacıların cinsiyet dağılımları nasıldır?

4. Araştırmalarda kullanılan deneysel desenlerin dağılımı nasıldır?

5. Deney sürelerinin dağılımları nasıldır?

6. Araştırmalara katılan öğrenci sayılarının (örneklemlerin) dağılımı nasıldır?

7. Araştırmalarda normallik testi yapılmış mı?

8. Araştırmalarda kalıcılık testi yapılmış mı?

9. Veri analizinde kullanılan istatistiksel testlerin dağılımları nasıldır?

\section{Yöntem}

\section{Araştırmanın Modeli}

Yürütülen çalışmada meta-analiz yöntemi kullanılmıştır. Son yıllarda eğitim alanında yapılan çalışmaların artmasıyla birlikte bu çalışmaların ortaya koyduğu sonuçları sistematik hale getirme ihtiyacı doğmuştur. Meta-analiz yöntemi ile yapılan araştırmaların sentezlenerek sonuçlarını kapsamlı ve aynı zamanda öz halde görebilmek mümkündür. Araştırmaların sentezlenmesinin, bilimsel 
gelişmelerin birikimli doğasına katkısı yadsınamaz olsa da, bu metodun artan akademik farkındalık ve gözde olmasının sebebi politika belirleyiciler ve uygulayıcılara sağladıklarıdır (Chalmers, Hedges ve Cooper 2002). Bu nedenle araştırmada meta-analiz yöntemi tercih edilmiştir. Meta-analiz çalışmaları aynı ya da ilişkili amaca sahip araştırmaların sonuçlarının bütünleştirilmesi sonucunda daha genellenebilir ve birçok araştırma ile doğrulanmış sonuçlara ulaşılabilir (Büyüköztürk, 2016).

\section{Evren ve Örneklem}

Araştırmanın evrenini 2001-2017 yılları arasında Matematik Eğitimi Ana Bilim Dalında "Matematik Eğitimi”" anahtar sözcükleri kullanılarak YÖK tez merkezi veri tabanına yüklenmiş, yazarı tarafından erişimlerine izin verilmiş olan Türkçe yazılmış lisansüstü tezler oluşturmaktadır. 2001-2017 yılları arasında yapılan çalışmaların tercih edilmesinde, literatürdeki yeni yöntem ve yaklaşımların 2000'li yılların başından itibaren eğitim araştırmalarındaki yoğunluğunun artış gösteriyor olması etkili olmuştur. Yapılan bu araştırmada deneysel desenli tezler ele alınmıştır.

\section{Veri Toplama Araçları ve Verilerin Analizi}

Literatür incelenerek geliştirilen deneysel araştırma inceleme formu veri toplama aracı olarak kullanılmıştır. Deneysel araştırma inceleme formu; tezlerin yıllara ve üniversitelere göre dağılımı, araştırmacıların cinsiyetleri, seçilen deneysel yöntem desenleri, uygulanan model-yöntem dağılımı, çalışılan örneklemin düzeyi ve sayısal dağılımı, araştırmaların kontrol grubu yöntem dağılımı, çalışılan konunun öğrenme ve alt öğrenme alanı, bağımlı ve bağımsız değişkenleri, deneyin uygulanma süresi, normallik ve kalıcılık testi ve veri analizinde kullanılan testler olmak üzere on altı farklı bölümden oluşmaktadır. Bu form araştırmacı tarafından hazırlanmış ve üç uzman tarafından okunarak forma son hali verilmiştir. İhtiyaç duyulan düzeltmelerden sonra araştırmaya dâhil edilen tezlere uygulanarak veriler toplanmıştır.

Verilerin analizi için, YÖK tez merkezine kayıtlı olan ve izinli (erişilebilir) lisansüstü tezlerin incelenmesi için belge tarama yöntemi ile içerik analizi seçilmiştir. Eldeki verileri açıklayıcı ilişkilere dönüştürmek ve tanımlamalar yapmak için kavramsallaştırmalar yapılır; bu kavramsallaştırmalar mantıksal olarak düzenlenerek çeşitli temalar belirlenir ve bu süreç verilerin kodlanması, temaların bulunması, kod ve temaların düzenlenmesi, sonuçların tanımlanarak yorumlanması şeklinde yürür (Yıldırım ve Şimşek, 2006). İncelenen tezlerin içerikleri, belirlenen kriterler göz önüne alınarak kapsamlı şekilde analiz edilip, elde edilen sayısal veriler Excel programında tablolaştırılmış ve yorumlanmıştır.

\section{Araştırmanın Geçerlik ve Güvenirliği}

Araştırmanın geçerliliği analizi yapılan çalışmaların geçerlilikleriyle doğru orantılıdır. Çalışmanın güvenilirliğini sağlamak için toplanan verilerin analizi, araştırmacılar ve matematik eğitimi alanında uzman bir akademisyen tarafından yapılmıştır. Ayrı ayrı yapılan analizlerde çalışmanın güvenilirlik hesabı için Miles ve Huberman'ın (1994) geliştirdiği formül işe koşulmuştur. Güvenirlik = Görüş Birliği/(Görüş Birliği + Görüş Ayrılı̆̆ı). Yapılan hesaplamaya göre araştırmanın güvenirliği \%89 olarak bulunmuştur. Bu oranın \%70'in üzerinde olması, çalışmanın güvenilir olduğu sonucunu ortaya koyar (Miles ve Huberman, 1994). Meta analiz çalışmalarında geçerlik ve güvenirliğin sağlanması önemlidir. Demiray'a (2013) göre meta analiz sürecinde geçerlik ve güvenirliğin sağlanabilmesi için dikkat edilmesi gereken durumlar aşağıda belirtilmiştir:

a. Meta analizde kullanılacak çalışmaların geçerlilikleri, analizi yapılacak çalışmaların geçerlilikleriyle orantılıdır.

b. Akademik çalışmaların değerlendirmesi yapılırken en az iki uzman tarafından incelenmesi sonuçların daha güvenilir olması açısından önemlidir.

\section{Bulgular}

Matematik Eğitimi alanında 2001-2017 yılları arasında tamamlanmış 308 tezin incelendiği bu çalışmada, yüksek lisans düzeyinde 94 ve doktora düzeyinde 17 olmak üzere toplam 111 tezin (\%36) deneysel desenle yapıldığ belirlenmiştir. Belirlenen kriterlere göre incelenen 111 deneysel tezden elde edilen bulgular bu bölümde alt problem sırasına göre ele alınmıştır. 
Birinci alt problem olan "Deneysel desenli tez sayıları yıllara göre nasıl bir değişim göstermektedir?" sorusunun cevabı için içeriklerine ulaşılabilen (izinli) ve 2001-2017 yılları arasında tamamlanmış lisansüstü tezlerin yıllara göre dağılımı Grafik 1'de gösterilmiştir.

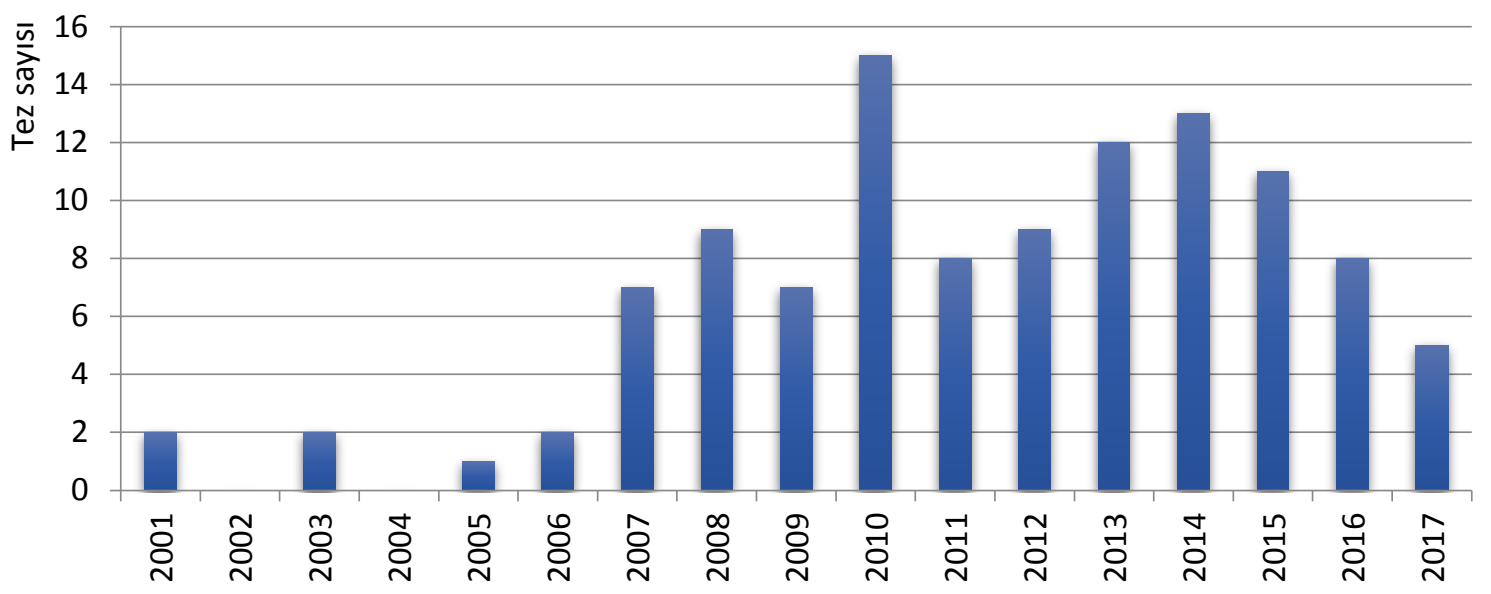

Grafik 1. Lisansüstü Tezlerin Yıllara Göre Dağıllımı

Grafik 1'e göre deneysel araştırma tezlerinin en fazla olduğu yıl 2010 (15 adet) dur. İnceleme sonucunda 2002 ve 2004 yıllarında Matematik Eğitimi alanında deneysel lisansüstü araştırmaya rastlanmamıştır. Yıllara göre 2014 yılına kadar artış gösteren araştırmaların 2014 yılından sonra azalma eğiliminde olduğu görülmektedir.

İkinci alt problem olan "Deneysel desenli tezlerin üniversiteler bazında dağılımları nasıldır?" sorusunun cevabı için incelenen tezlerin Türkiye'deki üniversitelere göre dağılımı Grafik 2'de görülmektedir.

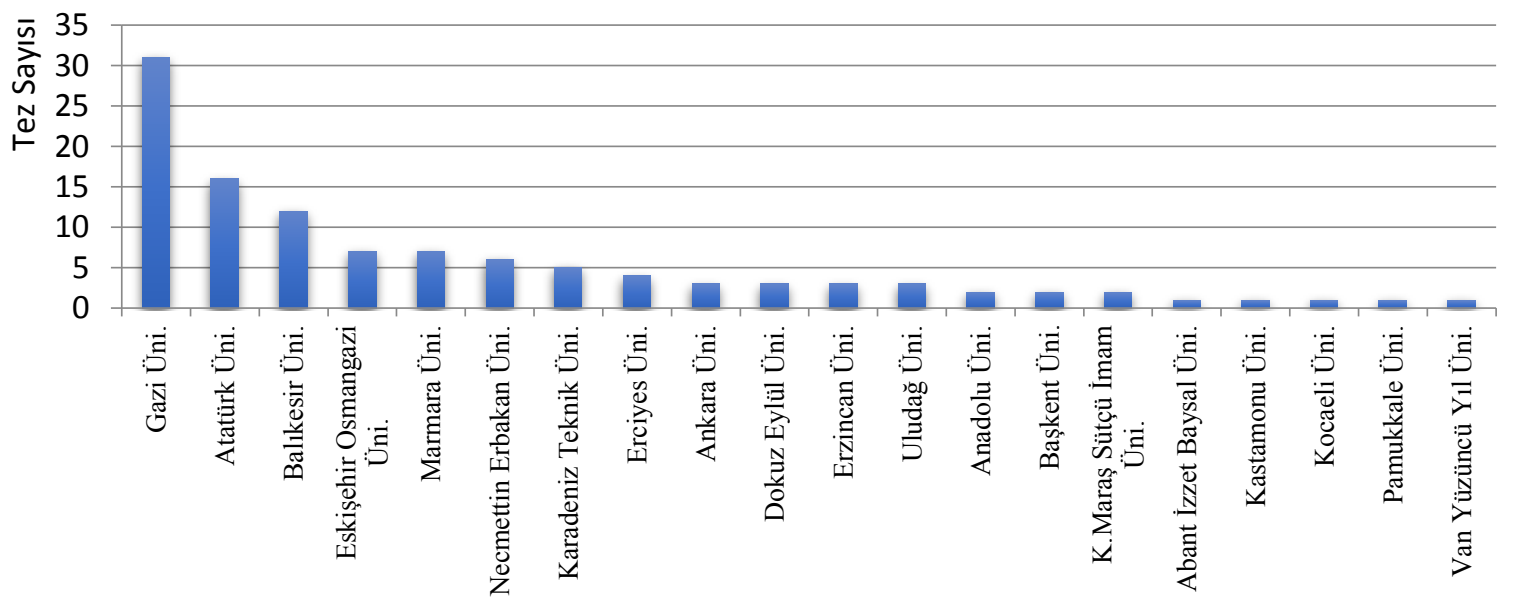

Grafik 2. Lisansüstü Tezlerin Üniversitelere Göre Dağılımı

Grafik 2'ye göre Matematik Eğitimi alanındaki deneysel tez araştırmalarının büyük çoğunluğu Gazi Üniversitesi (\%28), Atatürk Üniversitesi (\%14) ve Balıkesir Üniversitesi‘nde (\%11) yapıldığı görülmektedir.

Üçüncü alt problem olan "Araştırmacıların cinsiyet dağılımları nasıldır?" sorusunun cevabı için araştırmacıların cinsiyet dağılımları Grafik 3'te lisansüstü düzeylerine göre verilmiştir. İncelenen tezlerden elde edilen verilere göre deneysel araştırmaların \%52'sini kadınlar, \%48'ini erkekler gerçekleştirmiştir. 


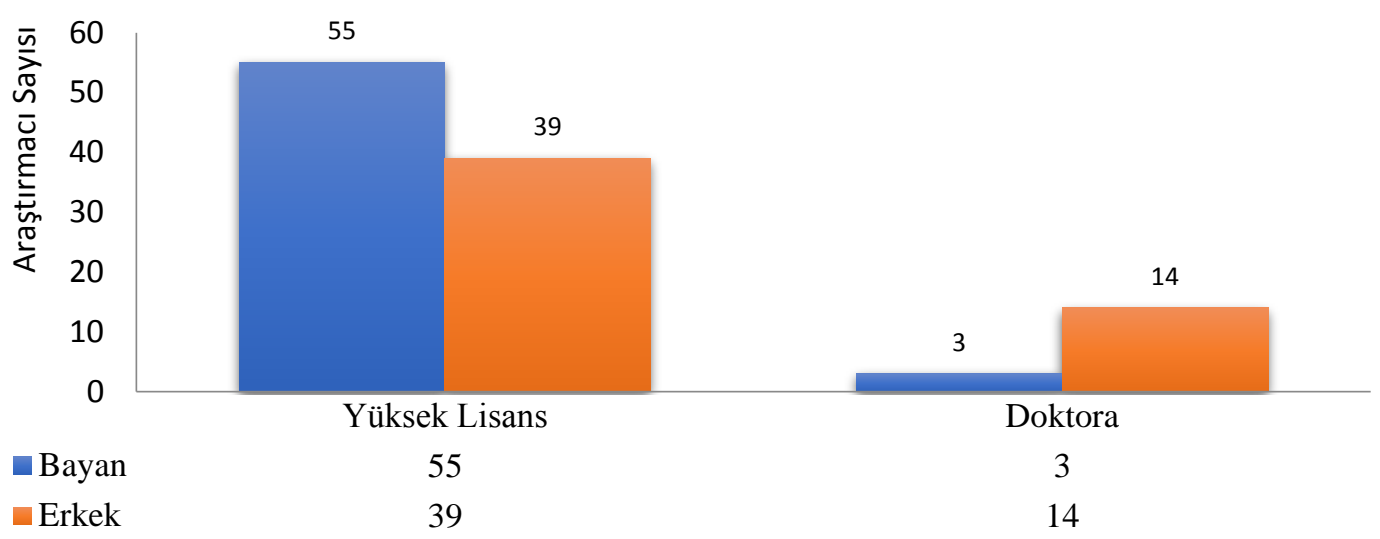

\section{Grafik 3. Araştırmacıların Cinsiyet Dağılımı}

Grafik 3'e göre yüksek lisans düzeyindeki deneysel çalışmaların \%59'u kadın araştırmacılara ait iken, \%41'ini erkek araştırmacıların yazdığı belirlenmiştir. Doktora düzeyindeki deneysel çalışmaların ise sadece \%18'i kadın akademisyenlere ait iken, \%82'si erkek araştırmacılar tarafından tamamlanmıştır. Dördüncü alt problem olan "Araştırmalarda kullanılan deneysel desenlerin dağılımı nasıldır?" sorusunun cevabı için yapılan incelemelere göre; deneysel araştırmaların \%94'ünde (104 tez) yarı deneysel desenin tercih edildiği, tam deneysel ( 2 tez), tek gruplu (3 tez) ve faktöriyel desenleri ( 2 tez) tercih edenlerin ise toplamda $\% 6$ ' $1 \mathrm{k}$ bir dilimi oluşturduğu görülmektedir.

Beşinci alt problem olan "Deney sürelerinin dağılımları nasıldır?" sorusunun cevabı için; araştırmaların deney süreçlerinin uygulama süreleri yüksek lisans düzeyinde ve doktora düzeyinde Grafik 4'te verilmiştir.

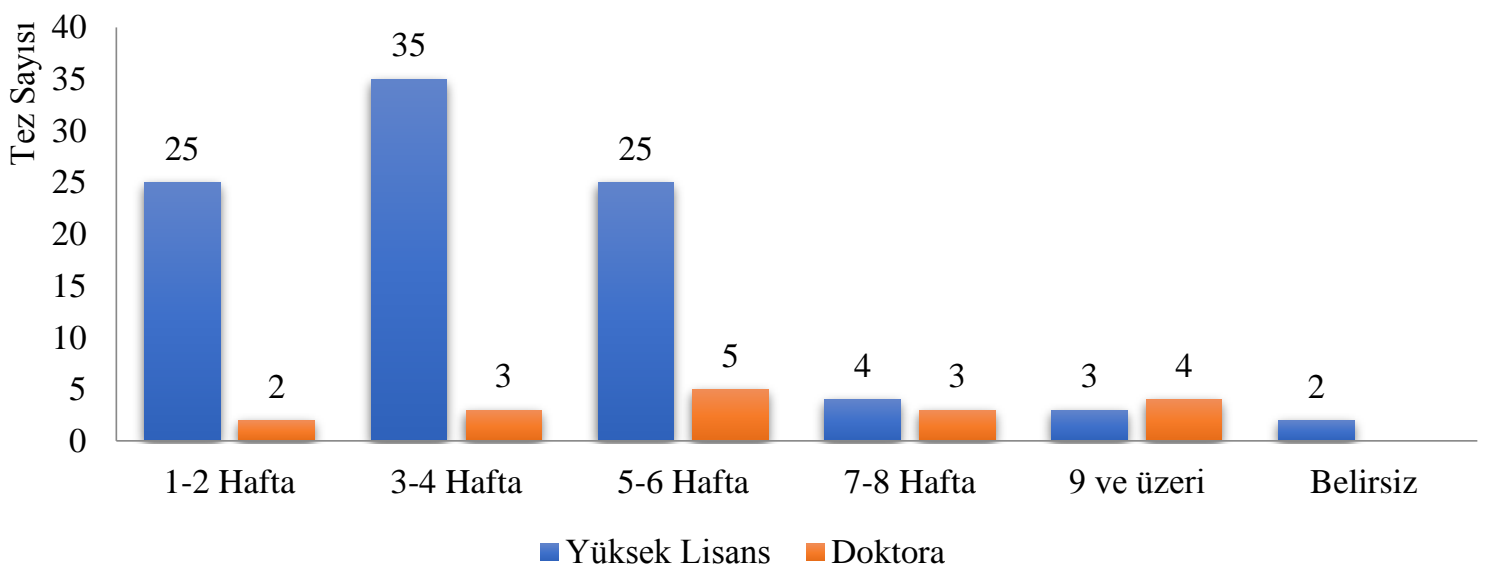

\section{Grafik 4. Deneylerin Uygulanma Süresi}

Grafik 4'e göre, 94 tane yüksek lisans düzeyinde deneysel araştırmanın 25 tanesinin (\%28) 1-2 hafta, 35 tanesinin (\%37) 3-4 hafta, 25 tanesinin (\%28) 5-6 hafta, 4 tanesinin (\%4) 7-8 hafta, 3 tanesinin (\%3) 9 hafta ve üzeri sürede yapıldığ 1 tespit edilmiştir. Bu sonuçlara göre yüksek lisans düzeyinde yapılan deneysel araştırmaların çoğunlukla 3-4 hafta dolaylarında yapıldığı görülmektedir. Ayrıca incelenen tezlerin 2 tanesinde uygulama süresine ilişkin bilgiye rastlanamamıştır. Grafik 4 incelendiğinde, 17 tane doktora düzeyindeki deneysel araştırmada; 2 tanesinin (\%12) 1-2 hafta, 3 tanesinin (\%18) 3-4 hafta, 5 tanesinin (\%29) 5-6 hafta, 3 tanesinin (\%18) 7-8 hafta, 4 tanesinin (\%23) 9 hafta ve üzeri sürede deneysel uygulamanın yapıldığı tespit edilmiştir. Bu sonuçlara göre doktora 
düzeyinde yapılan deneysel araştırmalarda çalışma süresi olarak 5-6 hafta aralığının daha çok tercih edildiği görülmektedir.

Altıncı alt problem olan "Araştırmalara katılan öğrenci sayılarının (örneklemlerin) dağılımı nasıldır?" sorusunun cevabı için; araştırmaların deney ve kontrol gruplarındaki toplam örneklem sayısının dağılımı Grafik 5'te verilmiştir. Deneysel araştırmalarda yapılan veri analizlerinde verilerin normal dağılım gösterip göstermediğine göre parametrik veya non-parametrik testlerin kullanılmasına karar verilmektedir.

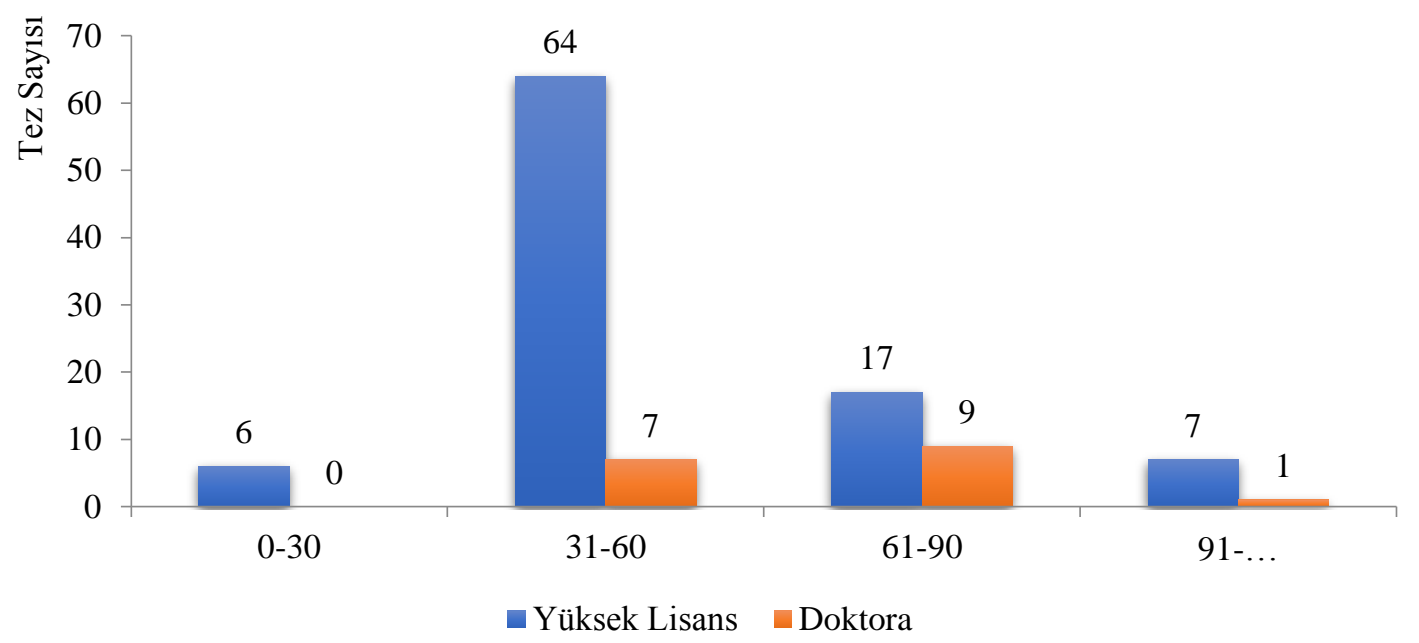

Grafik 5. Deneylerde Seçilen Örneklemin Sayısal Dă̆ı̆lımı

Grafik 5'e göre yüksek lisans düzeyindeki örneklem sayılarının \% 68'inin (64 tez) 31-60 aralığında, \%18'inin (17 tez) 61-90 aralığında, \%6'sının (6 tez) 0-30 aralığında ve \%8'inin (7 tez) 91 den fazla olduğu görülmektedir. Doktora düzeyindeki çalışmalarda ise 0-30 aralığında bir örneklemle hiç araştırma yapılmadığı, çalışmaların \%53'ünün (7 tez) 61-90 aralığında, \%41'inin (7 tez) örneklem sayısının ise 31-60 aralığında olduğu tespit edilmiştir.

Yedinci alt problem olan "Araştırmalarda normallik testi yapılmış mı?" sorusunun cevabı için yapılan incelemelere göre; yüksek lisans bazında 94 tezden 45 tanesinde (\%48) yapılıp, 49 tanesinde (\%52) yapılmadığı; doktora düzeyinde 17 tezden 12 tanesinde (\%71) yapıldığı, 5 tanesinde (\%29) yapılmadığ 1 belirlenmiştir.

Sekizinci alt problem olan "Araştırmalarda kalıcılık testi yapılmış mı?” sorusunun cevabı için yapılan incelemelere göre; yüksek lisans bazında kalıcılık testinin 94 tezden 34 tanesinde (\%36) yapılıp, 60 tanesinde (\%64) yapılmadığı; doktora düzeyinde 17 tezden 5 tanesinde (\%29) yapıldığı, 12 tanesinde (\%71) yapılmadığı belirlenmiştir.

Dokuzuncu alt problem olan "Veri analizinde kullanılan istatistiksel testlerin dağılımları nasıldır?" sorusunun cevabı için yapılan incelemelere göre; deneysel araştırmaların veri analizinde kullanılan parametrik ve non-parametrik testlerin, tezlerde kullanılma sayılarına ilişkin veriler yüksek lisans ve doktora bazında olacak şekilde Grafik 6'da verilmiştir. 


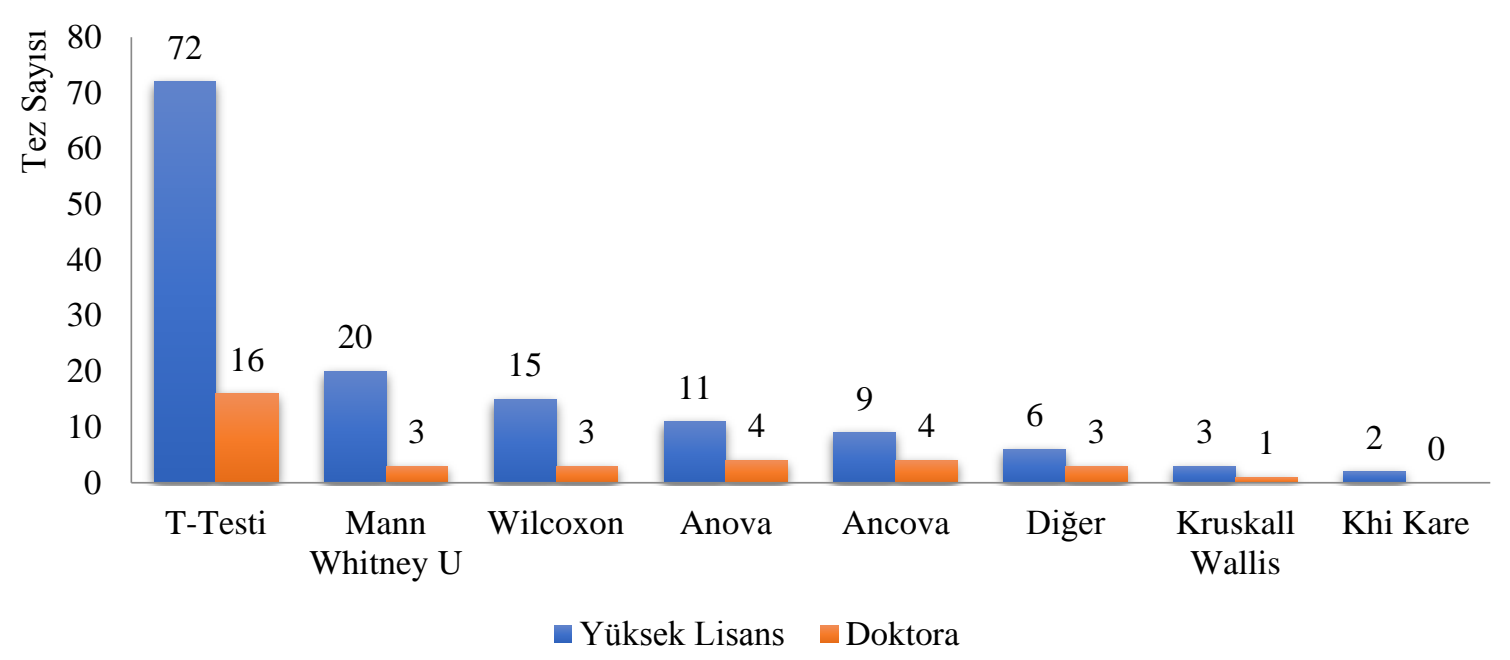

\section{Grafik 6. Veri Analizinde Kullanılan Testlerin Sayıları}

Grafik 6'daki verilere göre yüksek lisans düzeyinde yapılan 87, doktora düzeyinde 16 tezde kullanılan T-Testi deneysel araştırmalarda en fazla kullanılan istatistiki test olarak görülmektedir. (Grafikte belirtilen T-Testi ifadesinde ilişkili-ilişkisiz örneklemler T-testi bağımlı-bağımsız örneklemler T-testi vb. grupların tamamı birlikte değerlendirilmiştir.)

\section{Sonuç ve Tartışma}

Matematik eğitimi alanında deneysel desenli tezlerin 2001-2006 yılları arasında yok denecek kadar az olması, ülkemizde matematik eğitimi çalışmalarının o yıllardan sonra hız kazanmasıyla açıklanabilir. Zira Ulutaş ve Ubuz (2008) yaptıkları çalışmada Türkiye'de, 2000-2006 yılları arasında matematik eğitimi alanında yapılan çalışmaların azlığına dikkat çekmişlerdir. Matematik eğitimi alanında yapılan lisansüstü deneysel araştırma sayılarına bakıldığında; araştırmaların 2001 yılından 2014 yılına kadar artış trendinde oldukları gözlemlenirken, 2014 yılından sonra deneysel çalışmaların azalma eğiliminde olduğu söylenebilir. Bu durumun belki de; son dönemde matematik eğitiminde test edilecek bağımsız değişken sayısının azalmasından kaynaklandığını söylenebilir. Ancak yine de; deneysel araştırmaların eğitim alanındaki değişimlere sağladıkları katkılar dikkate alındığında, deneysel desenli çalışmalara hız kesmeden devam edilmesi gerekir.

Deneysel desenli lisansüstü araştırmaların üniversitelere göre sayıları dikkate alındığında; Gazi Üniversitesi'nin tek başına tüm çalışmaların yaklaşık olarak çeyreğini oluşturduğu görülmektedir. Bu durum Güven ve İbaçoğlu (2016) tarafindan yapılan, "Hayat bilgisi dersine yönelik tez çalışmaları ve makalelerin incelenmesi" başlıklı araştırmayla da benzerlik göstermektedir.

Araştırmacıların cinsiyetleri incelendiğinde; yüksek lisans düzeyinde bayan araştırmacı sayısının, doktora düzeyinde ise erkek araştırmacı sayısının fazla olduğu sonucuna ulaşılmıştır. Bu sonuç Balcı (2004) ve Dağdeviren (2017) tarafından yapılan araştırma sonuçlarıyla örtüşmektedir. Bu veriden hareketle yüksek lisans eğitimini tamamlayan bayan araştırmacıların büyük bir kısmının bir üst eğitim düzeyine devam etmedikleri söylenebilir.

Tezlerde kullanılan deneysel desenler incelendiğinde; çalışmaların neredeyse tamamına yakınının yarı deneysel desenli olduğu tespit edilmiştir. Bunun en önemli sebebi de eğitim araştırmalarında, okul ve sınıf ortamlarında öğrencileri gruplara ayırma aşamasında yansız atama yapmanın neredeyse imkânsız olmas1 gösterilebilir. Ancak incelenen tezlerde rastlanan tam deneysel desenli çalışmaların ayrıntılarına bakıldığında eğitim ortamlarında gerekli gayret gösterildiğinde tam deneysel çalışma yapmanın mümkün olduğu söylenebilir. Tam deneysel araştırmalarda sistematik bir inceleme yolu seçilir ve örneklem için rasgele yöntem tercih edilir. Ayrıca araştırmalarda, kontrollü çalışmalar 
yapılarak sonuç elde edilir ve süreç içerisinde iç ve dış faktörler en üst düzeyde kontrol altına alınarak veriler toplanır (Çepni, 2012).

Araştırmaların deneysel uygulama süreçlerine ilişkin elde edilen verilere göre; yüksek lisans düzeyindeki araştırmaların çoğunluğunun uygulama süresinin 6 haftadan az olduğu ve en fazla 3-4 hafta aralığında seçildiği görülmüştür. Deney süresinin bu denli kısa olması yüksek lisans seviyesinde yapılan çalışmaların geçerliliği ve niteliği hakkında da soru işaretleri oluşturmaktadır. Denenen öğretim yönteminin etkisini görmek için deney süresini mümkün olduğunca uzun tutmakta fayda olacaktır. Doktora düzeyindeki çalışmaların uygulama sürelerinin ise çoğunluğunun 5-6 hafta aralığında seçildiği tespit edilmiştir. Bu durum doktora çalışmalarında deneysel çalışmaların uygulama aşamalarının yüksek lisans çalışmalarına göre daha uzun sürdüğünü göstermektedir.

Çalışmaların büyük çoğunluğunda örneklem sayısının 31-60 aralığında olduğu görülmektedir. $\mathrm{Bu}$ sonuç Keskin'in (2014) “Öğrenme Stratejileri Konulu Lisansüstü Tezlerin İncelenmesi” adlı araştırmasında ele aldığ çalışmalarda katılımcı sayılarının \%48'inin 200 ve üzeri olmasıyla farklılık göstermektedir. İncelenen tezlerde ortalama 30-60 aralı̆̆ında bir örneklem büyüklüğü ile çalışmaların yapıldığı sonucuna ulaşılmıştır. Bu durumun deneysel desenli araştırmalar için kabul edilebilir seviyelerde olduğu söylenebilir.

Normallik testinin varlığına ilişkin yapılan incelemelere göre; yüksek lisans düzeyindeki deneysel araştırmaların yaklaşık yarısında, doktora düzeyindeki deneysel araştırmaların çoğunda normallik testinin yapıldığı tespit edilmiştir. Deneysel bir araştırmanın veri analizinde kullanılacak testlerin seçiminde verilerin normalliği büyük önem taşımaktadır. Bu bilgiye göre normallik testi yapılmadan seçilen analiz testleri sadece varsayım üzere seçildiğini göstermektedir. Bu da yapılan deneysel araştırmanın veri analiz güvenirliği açısından sorun teşkil etmektedir.

İstatistiksel veri analizleri deneysel araştırmaların sayısal kısmını oluşturmaktadır. Elde edilen bulgulara göre; deneysel araştırmaların büyük çoğunluğunda T-testinin kullanıldığ1 tespit edilmiştir. Bu sonuçlar Arık \& Türkmen (2009), İlhan (2011) ve Nacar (2015) tarafından yapılan çalışmalarla paralellik gösterirken, Polat (2010), Bağcı (2012) ve İşçi'nin (2013) çalışmalarında betimsel analizin en yüksek oranda kullanıldığı ve T-testinin ikinci sırada olduğu bulgusu ile farklılık göstermektedir. Deneysel araştırmaların uygulanma süreçlerinden belirli bir süre sonra yapılan kalıcılık testleri, bağımsız değişkenin etkisinin kalıcılı̆̆ ile ilgili bilgi edinmek için yapılmaktadır. İncelenen yüksek lisans ve doktora düzeylerindeki deneysel araştırmaların büyük çoğunluğunda kalıc1lık testlerinin yapılmadığı belirlenmiştir.

İncelenen tezler YÖK tez merkezi veri tabanı dikkate alınarak Türkçe dilinde yapılan araştırmalardan seçilmiştir. Elde edilen bulguların daha geniş bir evrene ulaşabilmesi için yabancı dilde yapılan deneysel araştırmaların da incelenmesi önerilmektedir. Eğitim alanındaki deneysel araştırmalarda genel olarak yarı deneysel desenin tercih edildiği bulgusuna ulaşılmıştır. Araştırmacıların, deneysel çalışmalarda gerekli örneklem seçme kriterlerini uygulamaları ve yarı deneysel yerine tam deneysel çalışma için gerekli koşulları sağlamaları tavsiye edilebilir. Bu sayede araştırmada elde edilen sonuçların bilimsel niteliğinin artacağı düşünülmektedir. Eğitim alanında yapılan deneysel araştırmaların büyük bölümünde, deneyin yapılma ve verileri elde etme süreçleri okul ortamlarında gerçekleştirildiği için öğretim sürecine etki etmeyecek şekilde planlama yapılabilir. Bu ayrıntının göz ardı edilmesinden dolayı deneylerin kontrol gruplarında fark edilemeyen konu eksiklikleri ortaya çıkabilir, ders öğretmeni bu eksiği tamamlamakta yetersiz kalabilir.

\section{Kaynakça}

Altunışık, R., Coşkun, R., Bayraktaroğlu, S., \& Yildirim, E. (2005). Sosyal bilimlerde araştırma yöntemleri. Sakarya Kitabevi, Adapazarı.

Arık, S., \& Türkmen, M. (2009). Eğitim bilimleri alanında yayınlanan bilimsel dergilerde yer alan makalelerin incelenmesi. The first International Congress of Educational Research, Çanakkale. 
Bağcı, Ş. (2012). Sınıf Öğretmenliği Lisansüstü Tezlerinin Karakteristik Özellikleri: Tematik, Metodolojik Ve İstatistiksel Yönelimler. (Yayınlanmamış Yüksek Lisans Tezi). Eskişehir Osmangazi Üniversitesi Eğitim Bilimleri Enstitüsü. Eskişehir.

Baki, A., Güven B., Karataş, İ., Akkan, Y., \& Çakıroğlu, Ü. (2011). Türkiye'deki matematik eğitimi araştırmalarındaki eğilimler: 1998 ile 2007 yılları arası. Hacettepe Üniversitesi Eğitim Fakültesi Dergisi, 40(1), 57-68.

Balcı, A. (2010). Sosyal Bilimlerde Araştırma: Yöntem, Teknik Ve İlkeler. (7.basım). Ankara: Pegem A Yayıncilik.

Balcı, S. (2004). Türkiye'de fen bilimleri eğitimi tezleri. Sekizinci Ulusal Eğitim Bilimleri Kurultayı, İnönü Üniversitesi Eğitim Fakültesi, Malatya.

Büyüköztürk, Ş. (2016). Bilimsel araştırma yöntemleri. Ankara: Pegem Akademi Yayınları.

Büyüköztürk, Ş. (2007). Deneysel desenler: Öntest- sontest kontrol gruplu desen ve SPSS uygulamalı veri analizi (Geliştirilmiş 2. bas.). Ankara: Pegem Yayınları.

Büyüköztürk, Ş. (2018). Sosyal bilimler için veri analizi el kitabı. Ankara: Pegem Akademi Yayınları.

Can, A. (2018). SPSS ile bilimsel araştırma sürecinde nicel veri analizi. Ankara: Pegem Akademi Yayınları.

Cebeci, S.(2002). Bilimsel Araştırma ve Yazma Teknikleri. İstanbul: Alfa Basım Yayım Dağıtım.

Chalmers, I., Hedges, L. V., \& Cooper, H. (2002). A brief history of research synthesis. Evaluation \& The Health Professions, 25(1), 12-37.

Cohen, L., Manion, L., \& Morrison, K. (2000). Research Methods in Education [5 th edn] London: Routledge Falmer. Teaching in Higher Education, 41, 21.

Çepni, S. (2012). Araştırma ve proje çalışmalarına giriş̧. Trabzon: Celepler Matbaa.

Çıng1, H. (1994). Örnekleme Kuramı. Ankara: Hacettepe Üniversitesi Fen Fakültesi Basımevi.

Demiray, P. (2013). Proje Tabanlı Öğrenme Modelinin Etkililiği: Bir Meta Analiz Çalışması. Yüksek Lisans Tezi, Ankara Üniversitesi Eğitim Bilimleri Enstitüsü. Ankara.

Elliot, J. (2005). Using narrative in social research: Qualitative and quantitative approaches. London: Sage Publications

Fraenkel, J. R., \& Wallen, N. E. (2006). How to design and evaluate research in education. Mc Grawall Hill.

Gökçe, B. (1992). Toplum bilimlerde araştırma (2.baskı). Ankara: Savaş Yayınları.

Gürbüz, S., \& Şahin, F. (2014). Sosyal bilimlerde araştırma yöntemleri. Ankara: Seçkin Yayıncılık.

Güven, B. ve İbaçoğlu T. (2016). Hayat bilgisi dersi kapsamında gerçekleştirilen araştırmalara ilişkin bir inceleme. 15.Uluslararası Sınıf Öğretmenliği Eğitimi Sempozyumu, Mersin.

İlhan, A. (2011). Matematik Eğitimi Araştırmalarında Tematik Ve Metodolojik Eğilimler: Uluslararası Bir Çözümleme. (Yayınlanmamış Yüksek Lisans Tezi). Eskişehir Osmangazi Üniversitesi Eğitim Bilimleri Enstitüsü. Eskişehir.

İşçi, S. (2013). Türkiye'de Eğitim Yönetimi Alanında Yapılmış Lisansüstü Tezlerin Tematik, Metodolojik Ve İstatistiksel Açıdan İncelenmesi. (Yayınlanmamış Yüksek Lisans Tezi). Eskişehir Osmangazi Üniversitesi Eğitim Bilimleri Enstitüsü. Eskişehir.

İşçil, N. (1997). Ticaret aritmetiği ve mali cebir. Ankara: Armağan Yayınevi.

Karasar, N. (1999). Bilimsel Araştırma Yöntemi, Nobel Yayın Dağıtım, 9. Basım, Ankara.

Keskin, A. (2014). Öğrenme Stratejileri Konulu Lisansüstü Tezlerin İncelenmesi. (Yayınlanmamış Yüksek Lisans Tezi). Dicle Üniversitesi Eğitim Bilimleri Enstitüsü. Diyarbakır.

Lubienski, S.T., \& Bowen, A. (2000). Who's counting? A survey of mathematics education research 1982-1998. Journal for Research in Mathematics Education, 31(5), 626-633.

Miles, M. B., \& Huberman, A. M. (1994). Qualitative data analysis: an expanded sourcebook. New York: Sage.

Nacar, S. (2015). 2005-2014 Yı1ları Arasında Üstün Yeteneklilerin Matematik Eğitimi Üzerine Yapılan Çalışmalar. (Yayınlanmamış Yüksek Lisans Tezi). İnönü Üniversitesi Eğitim Bilimleri Enstitüsü. Malatya. 
Polat, G. (2010). Eğitim Yönetimi ve Denetimi Anabilim Dalında Yapılmış Lisansüstü Tez Çalışmalarının İncelenmesi. (Yayınlanmamış Yüksek Lisans Tezi). Maltepe Üniversitesi Sosyal Bilimler Enstitüsü. İstanbul.

Reed, M.K., \& Owens, D.T. (2000). Research in mathematics education. ERIC Document Reproduction Service No.482988.

Robson, C. (1998). Real world research. Blackwell Publishers ltd., Oxford, UK.

Ulutaş, F., \& Ubuz, B. (2008). Matematik eğitiminde araştırmalar ve eğilimler: 2000 ile 2006 yılları aras1. Illköğretim Online, 7(3), 614-626.

Yıldırım A., \& Şimşek H.(2006). Sosyal bilimlerde nitel araştırma yöntemleri, 5. Baskı. Ankara: Seçkin Yayıncılık. 